\title{
Investigating Best Practice and Effectiveness of Leadership Wisdom among Principals of Excellent Secondary School Malaysia: Perceptions of Senior Assistants
}

\author{
Abdul Razaq Ahmad ${ }^{1}$, Mohamad Johdi Salleh ${ }^{2}$, Mohd Mahzan Awang ${ }^{1} \&$ Nazifah Alwani Mohamad ${ }^{2}$ \\ ${ }^{1}$ Faculty of Education, Universiti Kebangsaan Malaysia, UKM Bangi, Selangor, Malaysia \\ ${ }^{2}$ Institute of Education, International Islamic University Malaysia \\ Correspondence: Abdul Razaq Ahmad, Faculty of Education, Universiti Kebangsaan Malaysia, 43650 UKM \\ Bangi, Selangor, Malaysia. Tel: 603-8921-6296. E-mail: razaq@ukm.my
}

Received: May 7, 2013 Accepted: May 29, $2013 \quad$ Online Published: July 16, 2013

doi:10.5539/ies.v6n8p38 URL: http://dx.doi.org/10.5539/ies.v6n8p38

\begin{abstract}
The aim of the current study is to investigate the practices and effectiveness of leadership wisdom among the principals of excellent secondary schools as perceived by the Senior Assistants. This research employed survey approach by using a validated questionnaire. The respondents were 417 Senior Assistants, who were randomly selected from the principals of excellent secondary schools in Malaysia. The findings showed that the Senior Assistants' perceptions of principals' practices of leadership wisdom were positively at higher level regarding principals' application of their knowledge to benefit the staff as well as the whole school. Interestingly, the data show that the senior assistants' perceptions of practice effectiveness were also higher. The implication is that all senior assistants are appropriate for their duties in excellent schools. Also the study findings would inspire the educational leaders to enhance their practices of leadership wisdom to move forward the institution in the realization of Vision 2020 as well as Malaysia Education Plan 2013-2025.
\end{abstract}

Keywords: leadership wisdom, excellent school, school management, effectiveness, educational leaders

\section{Introduction}

\subsection{Challenges}

The continuous and major challenges of the educational reforms require effective leadership competent in dealing with the current issues, as well as leading the organizations towards excellent performance. The requirements are comprised of numerous individual characteristics, particularly appropriate knowledge competency (Ahmad, Rahim \& Seman 2013), communication skills, interpersonal relations, and leadership wisdom. Leaders require wisdom to make their ideas creative, practical, functional, convincing, and valuable, and accordingly they will be able to combine practical intelligence, analytical intelligence and emotional intelligence. This provides an insightful and challenging set of criteria for leaders to develop and deploy strategic choices with knowledge, wisdom, justice empowerment, resilience, faithfulness, integrity, and efficiency.

\subsection{Concept of Wisdom}

Wisdom can be defined as the capacity to take the right action at the right time. Stenberg (2002) asserted that leaders need wisdom because they need creative abilities to come up with ideas and analytical abilities to decide whether ideas are good. They need practical abilities to make their ideas functional and to convince others of the value of their ideas. They need wisdom to balance the effects of ideas on themselves, others and institutions in both the short and the long run. Furthermore, he stated that for successful intelligence there is a need to combine practical intelligence, analytical intelligence and emotional intelligence. On the same note, Davies and Davies (2010) admit that this provides an insightful and challenging set of criteria for leaders to develop in order to deploy strategic choices with wisdom and effectiveness.

Stenberg (2002) states that wisdom encompasses insight or insightful intuition, openness, evolution, expansion, heightening, deepening, inclusiveness, far-sightedness, wholeness, awareness, feelings, knowledge, visions, stories, care, encounters, involvements, choices and actions. It involves cooperation, interaction, dialogue, compassion, resilience and all the other things that bring us together without losing our individual integrity and 
dignity. Certainly, these factors would enhance relationship, interconnectedness, wholeness, sacredness, love, and togetherness which are highly essential for the effectiveness of leadership towards organizational success (Bush \& Glover, 2003). It means that a leader should have comprehensive characteristics of wisdom, especially, far-sightedness, integrity, love and compassion in a holistic context, intelligence about relationships, recognition of the relativity of rightness, as well as deep responsibility for the consequences of one's thoughts and actions including the subordinates (Whittington, 2010).

In general, leadership wisdom is characterized by certain intellectual capability, wholeness, expansiveness, inclusiveness, depth, and spiritual presence in a person's or culture's engagement with individual life, particularly concerning the school organization and overall environment.

\subsection{School Leadership Wisdom}

The continuous and big challenges of the educational reforms require effective leadership competent in dealing with current issues, as well as leading the organization towards excellent performance. The requirements are comprised of numerous individual characteristics, particularly appropriate knowledge competency, communication skills, interpersonal relation, and leadership wisdom. Fullan (2001) claims, the principals' roles are very complex and challenging. The changes which are applied are various and difficult. The principal is required to be a professional leader who takes appropriate action. Davies (2005) states that leadership is associated with direction-setting and inspiring others to make the journey to a new and improved state in relation to the school. Leadership is not the provenance of one individual but a group of people, who provide leadership in the school and, by doing so; they support and inspire others to achieve the best and considerable success in relation to their careers and accordingly in training their students. In other words, leadership is not set in isolation but is set in the context of organizations and the wider society (Quong \& Walker, 2010; Hofman \& Hofman, 2011).

Johnson and Kardos (2002) point out that an effective leader is one who is always in the school surroundings, focusing on teaching and learning processes, monitoring classrooms and giving feedback. The development and success of a school is in the hands of the school's principals, leader or administrator. In this sense, whatever they offer in terms of leadership determines the level of success and accomplishment of the organisation. In other words, leadership is possibly the most important and essential skill that leaders in any organisation should have because they are perceived to be the causal agent for the success or failure of the organisation or educational setting (Souicie, 1994; Cheng, 2010).

A wise leader should possess sufficient knowledge in the nature, niche, vision, mission, strategies, processes and desired ultimate outcome of the organisation. Excellence in knowledge increases humbleness and convinces a person how much more one needs to explore in the new areas of knowledge. The Holy Qur'an refers to it in a unique manner: "Those truly fear Allah, among His servants, who have knowledge, for Allah is exalted in Might, Oft-forgiving." (Qur'an El-Fathir: 28). Knowledge and skill are two primary elements or foundations of a successful organization (Awang et. al, 2013). Administrators should possess not only the required knowledge, but also the skills in performing their work. The more quality knowledge the administrators possess, the more they are qualified to undertake the job to the best of their abilities. Magnificently, Allah mentions in the Holy Quran that whoever wishes or intents to succeed in the world or hereafter must have adequate and vast knowledge.

King (2002) admits that the roles of educational leaders such as principals and senior assistants or superintendents have expanded during the past decade, which include a larger focus on teaching and learning, professional development, data-driven decision making and accountability. There is strong and growing evidence that principals can play a pivotal role in initiating and sustaining school improvement especially in terms of students' academic performance (Harris, 2004). To be successful in such initiatives, principals must motivate and encourage teachers, students, parents and other community members to join their efforts in creating positive and engaging school climates that increase the likelihood of improved academic achievement and other forms of students' performance (Hallinger \& Heck 1997; Leithwood \& Reihl, 2005). Bush (2011) states that the role of the principal is widely regarded as central for school improvement and enhanced students' outcomes.

The changes and continuous challenges regarding educational institution should be approached positively and creatively in order to acquire the possible benefits. The negative or pessimistic perceptions would obviously become stumbling block to the success of any organization. Hairuddin (2012) suggested that since leadership wisdom, in its wholeness, is intricately interconnected, interdependent and co-creative, they take challenges and complexity wisely, not as an opposition but as an opportunity of brighter life forward. They are responsible but not blaming, since we are all creating what is going on, engaged but not controlling, and interested in the many 
roles that we are or could be involved in any phenomenon, and the choices among them.

Stenberg (2002) states that leadership wisdom may realize deeper levels, and reveal much of what is needed to know to live wisely in the world. He maintains that it may entail deep empathy feelings, compassion, understanding, mutual aid and collaborative problem-solving. Resilience, compassion, unity-consciousness, brotherhood/sisterhood among staff, and some forms of aesthetics and conscience are all rooted in the resonant inner life of organizational interconnectedness and source of good and strong teamwork. Wisdom arises from being fully present and understanding history and consequences, especially as seen by those involved with diverse experiences and perspectives.

Diversity and exploration in regard to shared discovery can find wisdom profoundly important to organization and relevant for the communities or societies from which they originate. Wisdom leaders can deepen and boost their comprehension by integrating reason, logic and facts with intuition, body awareness, spiritual sensibilities, narrative intelligence, emotional intelligence, and other ways of apprehending the world. Many people with vast knowledge and appropriate experience serve humanity or their communities in deeply nonpartisan ways towards broad long-term benefit (Syed Othman \& Aidit, 1994).

Wisdom can also be knowledge, statements or solutions that arise from such understandings and envisioned outcomes. Leadership wisdom emerges from creative interaction among diverse parties and perspectives, in co-creative service to the common benefit and goal of the organization (Saleh, 2002). Wisdom may be always potentially present in its transcendently whole state and accumulated collective form, accessible through reflective thought, atonement, conversation, understanding, and collaboration which are essential factors for the success and high achievement of organizational performance. Cooperation and collaboration among workers are considered to be highly-rated virtues in Islam, as they could instill harmony and the rights of every individual into an organization (Al-Bureay, 1990). By instilling these values, job functions will run smoothly, as any conflict would be dealt with collaboratively. In the same line, Allah SWT elaborately commands in the al-Maidah Chapter, verse 2 that means ... 'and cooperate in righteousness and piety, but do not cooperate in sin and aggression'.

Mohamad Johdi, Jeeranan and Adnan (2011) stress that an educational organization consists of a community which is interdependent on each other. A school principal cannot run an institution without teachers; teachers cannot carry out lessons without students; students may not succeed without their parents' determination for them to excel; the school cannot run efficiently without supportive staff like the IT technicians, clerks, security personnel, janitors, etc. Teamwork and cooperation are vital and has to be implied or practiced every minute in the organization.

All in all, educational leadership should always appreciate the following characteristics: demonstrating intellectual wisdom, being reasonable in balancing the individual interest of all members of the school organization with school interest, being able to tolerate the implementation of a period of strategy but he/she needs to be strict about his/her achievement (Awang, Jindal-Snape, Barber, 2013), bearing the values created together with the members of the school organization, and applying his/her knowledge for the benefit of the members of the school organization and for school as a whole. In addition, leadership wisdom should have the capacity to transcend limited perspectives towards greater and deeper understandings as well as broader, longer-term beneficial outcomes.

Hence, it is essentially beneficial to conduct a study on the practices and effectiveness of leadership wisdom among the principals of secondary schools in Malaysia.

\section{Objectives of the Study}

The aim of the study is to examine the practices and effectiveness of leadership wisdom among the principals of excellent secondary schools as perceived by the Senior Assistants. The leadership in these schools has been observed in terms of the practices and effectiveness of the school principals leading towards the schools' high achievement in accordance with the schools' objectives.

\section{Research Questions}

The current study intents to answer the following research questions:

1) What is the practice of leadership wisdom among principals of excellent secondary schools as perceived by the senior assistants?

2) How do the senior assistants perceive the effectiveness of the leadership wisdom practices among the school principals? 
3) What is the best practice of leadership wisdom among principals of excellent secondary schools as perceived by senior assistants?

4) What is the most effective practice of leadership wisdom among principals of excellent secondary schools as perceived by senior assistants?

\section{Method}

The study involved 417 respondents who are educational leaders in the government secondary schools, particularly the Senior assistants, who were selected randomly. The rationale for choosing the senior assistants is that they have a lot of experience and knowledge as they have served many principals in the field. The Senior Assistants comprises the Senior Assistants of Administration, Senior Assistants of Student Affairs, Senior Assistants of Co-curriculum, and Senior Assistants of Afternoon Session. The sampling for this study has been chosen from secondary schools in Selangor which have demonstrated excellent performance in academic achievements, particularly in the Lower Secondary Assessment or Penilaian Menengah Rendah (PMR) within three years from 2008 to 2010 .

Questionnaire has been used as a research instrument for the data collection purpose. Questionnaire was chosen because of its capability to survey a large sample in a short period of time at a lower cost. Apart from that, this survey method is appropriate for sensitive questions because the respondents' identity will be kept confidential and thus encouraging them to give honest responses (Sekaran, 2000).Some experts in the field were recruited to establish the face and content validity of the questionnaire. Moreover, to determine the reliability and validity of the questionnaire, a pilot study was carried out using the Cornbach Alph analysis. The analysis result showed that all the items in the construct indicate high level of reliability, i.e., between $0.81-0.90$ revealing that all items are at acceptable.

The data collected from the survey was analysed using the most commonly used statistical software package in the social sciences which is the Statistical Package for Social Science (SPSS) version 17.0. To analyze the obtained data, descriptive statistics such as mean score, standard deviation and frequency count were used. Furthermore, in order to analyse the demographic variables of the respondents, particularly the Senior Assistants, descriptive statistics was employed. Interpretation of mean scores are: 1.00-2.33 (low level), 2.34-3.67 (average level), and 3.685-5.00 (high level).

\section{Results}

The following sections discuss the analysis and findings of the study, in which the respective research questions are answered subsequently.

\subsection{Research Question 1: What is the Practice of Leadership Wisdom among Principals of Excellent Secondary} Schools in Malaysia as Perceived by the Senior Assistants?

The practice of leadership wisdom among principals of excellent secondary schools in Malaysia, as perceived by the Senior Assistants, is shown in Table 1 below.

Table 1. Principals' Practice of Wisdom as Perceived by the Senior Assistants $(n=417)$

\begin{tabular}{|c|c|c|c|c|}
\hline Item & $\begin{array}{l}\text { Mean } \\
\text { SD }\end{array}$ & Scale & $n$ & $\begin{array}{l}\text { Percentage } \\
(\%)\end{array}$ \\
\hline \multirow[t]{5}{*}{ The principal always demonstrates his/her intellectual wisdom. } & \multirow[t]{5}{*}{$\begin{array}{l}4.4101 \\
.7103\end{array}$} & $\begin{array}{l}\text { Once in a } \\
\text { while }\end{array}$ & 6 & 1.4 \\
\hline & & Sometimes & 36 & 8.6 \\
\hline & & Fairly-often & 156 & 37.4 \\
\hline & & Frequently & 219 & 52.5 \\
\hline & & Total & 417 & 100.0 \\
\hline \multirow[t]{3}{*}{$\begin{array}{l}\text { The principal is reasonable in balancing the individual interest of } \\
\text { all members of the school organization with school interest. }\end{array}$} & \multirow[t]{3}{*}{$\begin{array}{l}4.2590 \\
.6521\end{array}$} & $\begin{array}{l}\text { Once in a } \\
\text { while }\end{array}$ & 3 & 0.7 \\
\hline & & Sometimes & 39 & 9.4 \\
\hline & & Fairly-often & 222 & 53.2 \\
\hline
\end{tabular}




\begin{tabular}{|c|c|c|c|c|}
\hline \multirow{5}{*}{$\begin{array}{l}\text { The principal can tolerate the implementation of period of } \\
\text { strategy but he/she is strict towards its achievement. }\end{array}$} & \multirow{5}{*}{$\begin{array}{l}4.3813 \\
.6185\end{array}$} & Frequently & 153 & 36.7 \\
\hline & & Total & 417 & 100.0 \\
\hline & & $\begin{array}{l}\text { Once in a } \\
\text { while }\end{array}$ & 4 & 1.2 \\
\hline & & Sometimes & 20 & 5.0 \\
\hline & & Fairly-often & 207 & 49.6 \\
\hline \multirow{5}{*}{$\begin{array}{l}\text { The principal always holds on the values created together with the } \\
\text { members of the school organization. }\end{array}$} & \multirow{5}{*}{$\begin{array}{l}4.3741 \\
.6732\end{array}$} & Frequently & 186 & 44.6 \\
\hline & & Total & 417 & 100.0 \\
\hline & & $\begin{array}{l}\text { Once in a } \\
\text { while }\end{array}$ & 5 & 1.4 \\
\hline & & Sometimes & 28 & 6.5 \\
\hline & & Fairly-often & 189 & 45.3 \\
\hline \multirow{6}{*}{$\begin{array}{l}\text { The principal always applies his/her knowledge for the benefit of } \\
\text { the members of the school organization and for school as a whole. }\end{array}$} & & Frequently & 195 & 46.8 \\
\hline & & Total & 417 & 100.0 \\
\hline & 4.4532 & Sometimes & 28 & 6.7 \\
\hline & 0.6281 & Fairly-often & 168 & 40.3 \\
\hline & & Frequently & 221 & 53.0 \\
\hline & & Total & 417 & 100.0 \\
\hline
\end{tabular}

\section{SD: Standard Deviation}

Scale: 1-Not at all, 2-Once in a while, 3-Sometimes, 4-Fairly-often, 5-Frequently

Table 1 demonstrates, the item 'The principal always demonstrates his/her intellectual wisdom', which acquired mean score of 4.41 and Standard Deviation of 0.71. The item 'The principal is reasonable in balancing the individual interest of all members of the school organization with school interest' obtained mean score of 4.2 and standard deviation of 0.6521 . The next item, 'The principal can tolerate the implementation of period of strategy, but he/she is strict towards its achievement' obtained the mean score of 4.38 and standard deviation of 0.6732 . While the item 'The principal always holds on the values created together with the members of the school organization' shows mean score of 4.37 and standard deviation of .6732, the final item, 'The principal always applies his/her knowledge for the benefit of the members of the school organization and for school as a whole' displayed mean score of 4.45 and standard deviation of 0.6281 .

5.2 Research Question 2: How do the Senior Assistants Perceive the Effectiveness of the Leadership Wisdom Practices among the School Principals?

The senior assistants' perception of the effectiveness of the leadership wisdom among the principals of excellent secondary in Malaysia is shown in Table 2.

Table 2. Principals' Effectiveness of Wisdom as Perceived by the Senior Assistants ( $n=417)$

\begin{tabular}{lllll}
\hline Item & $\begin{array}{l}\text { Mean } \\
\text { SD }\end{array}$ & Scale & n & $\begin{array}{l}\text { Percentage } \\
(\%)\end{array}$ \\
\hline The principal always demonstrates his/her intellectual wisdom. & $\begin{array}{l}4.21 \\
0.72\end{array}$ & $\begin{array}{l}\text { Rarely } \\
\text { effective }\end{array}$ & 6 & 1.4 \\
& & $\begin{array}{l}\text { Quite } \\
\text { effective }\end{array}$ & 57 & 13.7 \\
& & Effective & 193 & 46.2 \\
& & Very & 161 & 38.6 \\
& & effective & \\
& & Total & 417 & 100.0 \\
\hline
\end{tabular}


The principal is reasonable in balancing the individual interest of all members of the school organization with school interest.
4.07

0.70

\begin{tabular}{|c|c|c|c|}
\hline \multirow[t]{5}{*}{$\begin{array}{l}4.07 \\
0.70\end{array}$} & $\begin{array}{l}\text { Rarely } \\
\text { effective }\end{array}$ & 5 & 1.2 \\
\hline & $\begin{array}{l}\text { Quite } \\
\text { effective }\end{array}$ & 66 & 15.8 \\
\hline & Effective & 228 & 54.7 \\
\hline & $\begin{array}{l}\text { Very } \\
\text { effective }\end{array}$ & 114 & 27.3 \\
\hline & Total & 417 & 100.0 \\
\hline \multirow[t]{5}{*}{$\begin{array}{l}4.19 \\
0.62\end{array}$} & $\begin{array}{l}\text { Rarely } \\
\text { effective }\end{array}$ & 4 & 0.9 \\
\hline & $\begin{array}{l}\text { Quite } \\
\text { effective }\end{array}$ & 39 & 9.4 \\
\hline & Effective & 249 & 59.7 \\
\hline & $\begin{array}{l}\text { Very } \\
\text { effective }\end{array}$ & 126 & 30.2 \\
\hline & Total & 417 & 100.0 \\
\hline \multirow[t]{5}{*}{$\begin{array}{l}4.15 \\
0.72\end{array}$} & $\begin{array}{l}\text { Rarely } \\
\text { effective }\end{array}$ & 9 & 2.2 \\
\hline & $\begin{array}{l}\text { Quite } \\
\text { effective }\end{array}$ & 54 & 12.9 \\
\hline & Effective & 216 & 51.8 \\
\hline & $\begin{array}{l}\text { Very } \\
\text { effective }\end{array}$ & 138 & 33.1 \\
\hline & Total & 417 & 100.0 \\
\hline \multirow[t]{5}{*}{$\begin{array}{l}4.23 \\
0.66\end{array}$} & $\begin{array}{l}\text { Rarely } \\
\text { effective }\end{array}$ & 3 & 0.7 \\
\hline & $\begin{array}{l}\text { Quite } \\
\text { effective }\end{array}$ & 45 & 10.8 \\
\hline & Effective & 219 & 52.5 \\
\hline & $\begin{array}{l}\text { Very } \\
\text { effective }\end{array}$ & 150 & 36.0 \\
\hline & Total & 417 & 100.0 \\
\hline
\end{tabular}

The principal can tolerate the implementation of period of strategy, but he/she is strict towards its achievement.

4.1

0.62

The principal always holds on the values created together with the members of the school organization.

The principal always applies his/her knowledge for the benefit of the members of the school organization and for school as a whole.

\section{SD: Standard Deviation}

Scale: 1-Not effective, 2-Rarely effective, 3-Quite effective, 4-Effective, 5-Very effective

Table 2 shows the effectiveness of the item 'The principal always demonstrates his/her intellectual wisdom', which obtained mean score of 4.21 and standard deviation of 0.7299 . The next item 'The principal is reasonable in balancing the individual interest of all members of the school organization with school interest' gained the score mean of 4.07 and standard deviation of 0.7026 , while the item 'The principal can tolerate the implementation of period of strategy but he/she is strict towards its achievement' acquired mean score of 4.19 and standard deviation of 0.6241 . The item 'The principal always holds on the values created together with the members of the school organization' obtained the mean score of 4.1583 and standard deviation of 0.7249 . Finally, the effectiveness of the item 'The principal always applies his/her knowledge for the benefit of the members of the school organization and for school as a whole' acquired the mean score of 4.23 and standard deviation of 0.6657 . 
The senior assistants' perceptions of the best practices of principals regarding wisdom were revealed in the item 'The principal always applies his/her knowledge for the benefit of the members of the school organization and for school as a whole' with mean score of 4.45 and Standard Deviation of 0.6281 . This item was rated as 'frequently' by $53.0 \%$ (221) of the senior assistants and perceived as 'fairly-often' by $40.3 \%$ (168) of them. In addition, $6.7 \%$ (28) of them identified this practice as 'sometimes'.

The second highest practice of wisdom among principals as perceived by senior assistants was the item 'The principal always demonstrates his/her intellectual wisdom' with mean score of 4.41 and standard deviation of 0.7103 . This item was rated as 'frequently' by $52.5 \%$ (219) of the senior assistants and perceived as 'fairly-often' by $37.4 \%$ (156) of them. In addition, $8.6 \%$ (36) of them identified this practice as 'sometimes' and 'once in a while' $1.4 \%$ (6).

\subsection{Research Question 4: What is the Most Effective Practice of Leadership Wisdom among Principals of Excellent Secondary Schools in Malaysia?}

The senior assistants' perceptions of effectiveness were highest on the item 'The principal always applies his/her knowledge for the benefit of the members of the school organization and for school as a whole' with mean score of 4.23 and standard deviation of 0.6657 . This item was rated as 'very effective' by $36.0 \%(150)$ of them and $52.5 \%$ (219) opted for 'effective'. Moreover, $10.8 \%$ (45) and $0.7 \%$ (3) perceived the practice as 'quite effective' and 'rarely effective' respectively from the total of 417 respondents.

The second highest respondents' selections in relation to the principals' effectiveness of wisdom as perceived by the senior assistants was the item 'The principal always demonstrates his/her intellectual wisdom' with mean score of 4.21 and standard deviation of 0.7299 . Likewise, 38.6\% (161) of the senior assistants identified this item as 'very effective', $46.2 \%$ (193) as 'effective', 13.7\% (57) as 'quite effective', and $1.4 \%$ (6) as 'rarely effective'.

\section{Discussion}

The senior assistants' perceptions of leadership wisdom practice effectiveness among principals of excellent secondary schools were highest regarding the item 'The principal always applies his/her knowledge for the benefit of the members of the school organization and for school as a whole', and the second widely chosen item was the item 'The principal always demonstrates his/her intellectual wisdom'. These were followed by the items 'The principal can tolerate the implementation of period of strategy but he/she is strict towards its achievement', 'The principal always holds on the values created together with the members of the school organization', and 'The principal is reasonable in balancing the individual interest of all members of the school organization with school interest', respectively.

The overall result reveals senior assistants' perceptions of leadership wisdom practice and effectiveness which were very high and very effective. This indicates that the principals of excellent secondary schools in Malaysia practice 'very highly' and 'very effectively' the leadership wisdom in their organizations.

In fact, this is one of the important aspects which should be given high attention in order to achieve tremendous accomplishment in the education system. Indeed, the subject of school leadership wisdom has attracted so much attentions of the governments around the world especially those who are embarking on massive education reforms in their education systems. The biggest problem faced by many of these countries is the realization of a wise school which is seen as an impetus not only to the success of the school, but also to the national agenda of each country. The key to the wisdom is inevitably the quality of leadership in the school organization.

Regardless of any style applied, effective and wise leadership needs to be able to prepare people to deal with the diverse situations in a pluralistic local situation and world at present. Skills are essential for effective leadership including social and interpersonal skills, active listening, facility in communication, presentation skills, group dynamics, goal setting, negotiation and conflict resolution.

The essential responsibility and accountability of educational leaders were associated with setting the new paradigm of education, including teaching skills related to wisdom and transformation, educating the youth and lifelong adult education, initiating experiential and multi-modal learning, providing education to recognize humanity as a living system embedded in larger natural living systems, which are embedded, in turn, in a far greater and fundamentally spiritual reality, i.e., a conscious and creative force, learning about love, and fostering altruism and generosity of spirit.

Finally, leaders need wisdom because they need creative and practical abilities to make their ideas functional, convince others of the value of their ideas, and balance the effects of ideas on themselves, others and institutions in both the short and the long run. There is a need to combine practical intelligence, analytical intelligence as well as emotional intelligence. This provides an insightful and challenging set of criteria for leaders to develop in 
order to deploy strategic choices with wisdom and effectiveness. Islam encourages all its adherents to acquire the necessary knowledge of things and specialization before executing any action or work. On the same note, the great Prophet has advised: "Whoever wishes for the world need to have knowledge, whoever wishes for the hereafter need to have knowledge, whoever wishes for both needs to have knowledge". The Prophet essentially admitted, "If you grant a job to someone who is not knowledgeable, just wait for the destruction". This is to prove and highlight the paramount importance of leaders' knowledge and wisdom.

\section{Conclusion}

The current study discovered that the senior assistants' perceptions of leadership wisdom effectiveness among the principals were above mean, i.e., 4.000. These were supported by very high score on 'Fairly Often' and 'Frequently' where all five items achieved above $80.0 \%$. The result indicates that the principals of excellent secondary schools in Malaysia practice leadership wisdom 'very highly and effectively'. It is hoped that the result of the study would inspire the educational leaders to enhance their leadership practices, particularly the leadership wisdom. This is to ensure that all educational leaders practice leadership wisdom effectively to move forward the institution in the realization of the National Key Result Area (NKRA) for Education, 1-Malaysia, the Vision 2020, and the newly launched Malaysia Education Plan 2013-2025.

\section{References}

Ahmad, A. R., Rahim, A., \& Seman, A. A. (2013). Active learning through History Subject towards Racial Unity in Malaysia. The Social Science, 8(1), 19-24.

Al-Bureay, M. A. (1990). Management and administration in Islam. Dhaharan: King Fahd University of Petroleum and Minerals.

Ali Mohammad Jubran Saleh. (2002). Educational Administration: An Islamic Perspective. Kuala Lumpur: A. S. Nordeen.

Al-Quran al-Karim. (2008). Translation. Riyadh: Maktab Darussalam.

Awang, M. M., Ahmad, A. R., Wahab, J. L. A., \& Mamat, N. (2013). Effective teaching strategies to encourage learning behaviour. IOSR Journal, 8(2), 35-40.

Awang, M. M., Jindal-Snape, D., \& Barber, T. (2013). A documentary analysis of the government's circulars on positive behaviour enhancement strategies. Asian Social Science, 9(5), 203-208. http://dx.doi.org/10.5539/ass.v9n5p203

Bush, T., \& Glover, D. (2003). School leadership: Concepts and evidence, Nottingham: NCSL.

Bush, T. (2011). Becoming a school principal: Exciting opportunity or daunting challenge? Educational Management, Administration \& Leadership, 39(5), 514-515. http://dx.doi.org/10.1177/1741143211409506

Cheng, Y. C. (2010). A topology of three-wave models of strategic leadership in education. International Studies in Educational Administration, 38(1), 35-54.

Davies, B. (2005). The essentials of school leadership. London: Paul Chapman \& Corwin Press.

Davies, B., \& Davies, B. J. (2010). The nature and dimensions of strategic leadership. International Studies in Educational Administration, 38(1), 5-21.

Department of Education Selangor. (2011). Selangor PMR Results. Unpublished data.

Fullan, M. (2001). The new meaning of educational change (3rd ed.). New York: Teachers College Press.

Hairuddin Mohd. Ali, \& Muhamad Bustaman Abdul Manaf. (2010). School Strategic Planning. Selangor: PTS Professional Publishing.

Hallinger, P., \& Heck, R. (1997). Exploring the principal's contribution to school effectiveness. School Effectiveness and School Improvement, 8(4), 1-35.

Harris, A. (2004). School leadership and school improvement: A simple and complex relationship. School Leadership \& Management, 24(1). http://dx.doi.org/10.1080/1363243042000172778

Hofman, W. H. A., \& Hofman, R. H. (2011). Smart management in effective schools: Effective management configurations in general and vocational education in the Netherlands. Educational Administration Quarterly, 47(4), 620-645. http://dx.doi.org/10.1177/0013161X11400186

King, D. (2002). The changing shape of leadership. Educational Leadership, 59(8), 61-63. 
Krejcie, R. V., \& Morgan, D. W. (1970). Determining sample size for research activities. Educational and Psychological Measurement, 30, 607-610.

Leithwood, K., \& Riehl, C. (2005). What we know about successful school leadership. In W. Firestone, \& C. Riehl (Eds.), A new agenda: Directions for research on educational leadership. New York: Teachers College Press.

Leithwood, K., Day, C., Sammons, P., Harris, A., \& Hopkins, D. (2006). Successful school leadership: What is it and how it influences pupil learning. University of Nottingham: NCSL.

Ministry of Education. (2006). Education Development Plan 2006 - 2010. Kuala Lumpur: Education Planning and Research Division.

Ministry of Education, Malaysia. (2012). Malaysia Education Plan - Blue Print 2013-2025. Communication and Corporate Unit, Ministry of Education Malaysia. Kuala Lumpur: Putrajaya.

Mohamad Johdi Salleh, Jeeranan Kornkasem, \& Adnan Abdul Rashid. (2011). Management System of Islamic Private Secondary Schools in Bangkok, Thailand. Journal of The Islamic Quarterly, 55(1), 21.

Quong, T., \& Walker, A. (2010). Seven Principles of Strategic Leadership. International Studies in Educational Administration, 38(1), 22-34.

Sekaran, U. (2000). Research methods for business: A skill building approach (3rd ed.). New York: John Wiley \& Sons, Inc.

Soucie, D. (1994). Effective managerial leadership in sport organisations. Journal of Sport Management, 8, 1-13.

Stenberg, R. J. (2002). Wisdom, schooling and society. Keynote presentation to the 2002 International Thinking Skills Conference, Harrogate, UK.

Syed Othman Alhabshi, \& Aidit Haji Ghazali (1994). Islamic Values and Management. Kuala Lumpur: Institute of Islamic Understanding Malaysia.

Whittington, R. (2010). What is strategy - and does it matter? (2nd ed.). London: Thomson Learning.

\section{Copyrights}

Copyright for this article is retained by the author(s), with first publication rights granted to the journal.

This is an open-access article distributed under the terms and conditions of the Creative Commons Attribution license (http://creativecommons.org/licenses/by/3.0/). 